\title{
EFFECTIVENESS OF BEAMS GAME AND PLASTICINE GAME ON COGNITIVE DEVELOPMENT IN EARLY CHILDHOOD EDUCATION, IN KEDIRI, EAST JAVA
}

\author{
Sutik', Zenny Priyanti Lasdiana'), Anik Nuridayanti3) \\ 1)Department in Nursing, School of Health Sciences \\ Ganesha Husada, Kediri, East Java \\ 2)Bachelor Program in Nursing, School of Health Sciences \\ Ganesha Husada, Kediri, East Java \\ 3)Department in Nursing, School of Health Sciences \\ Ganesha Husada, Kediri, East Java
}

\begin{abstract}
Backgrounds: Cognitive development was the primary thing for children, especially in the golden age period. In Indonesia, data from the Ministry of Education and Culture, 2018, showed that the average number of pre-school age children had low cognitive development (56.4\%). The game was one of the efforts to improve cognitive development. This study aimed to analyze the effectiveness of using beams and plasticine games on the cognitive development of pre-school children.

Subjects and Method: This was a quasi-experiment post-test only with control design. The study was conducted in Pelita Ilmu and Dharma Wanita Early Childhood Education, Kediri, East Java, in March 2020. A total of 40 pre-school children were divided into 20 subjects receiving beams game and 20 subjects receiving plasticine game. The dependent variable was cognitive development. The independent variables were using beams and plasticine games. The data was collected by observation sheet assessment AUD and analyzed by Mann Whitney test.

Result: The mean rank of cognitive development pre-school children in the beams game group was 24.93, while the mean rank of the plasticine games group was 15.08, and it was statistically significant $(\mathrm{p}=0.007)$

Conclusion: Beams games is more effective than using plasticine games on the cognitive development of pre-school children.

Keywords: beams game, plasticine game, cognitive development, pre-school

\section{Correspondence:}

Sutik. Department in Nursing, School of Health Sciences Ganesha Husada. Jl. Soekarno Hatta Gg. Budaya Cipta 2 No. 2 Kediri, East Java. Email: putrigrace98@yahoo.co.id. Mobile: +6281330783574 .
\end{abstract}

